\title{
PENGARUH PENAMBAHAN EKSTRAK DAUN KELOR (Moringa Oleifera L.) TERHADAP KUALITAS YOGHURT
}

\author{
Agung Diantoro ${ }^{1)}$, Muzaki Rohman ${ }^{1)}$, Ratna Budiarti ${ }^{1)}$, Hapsari Titi Palupi ${ }^{1)}$ \\ ${ }^{1)}$ Program studi Ilmu dan Teknologi Pangan, Fakultas Pertanian Universitas Yudharta Pasuruan \\ Email: agung.diantoro@yahoo.com
}

\begin{abstract}
Abstrak
Kelor adalah tanaman yang tumbuh subur di Indonesia dengan berbagai manfaat yang terkandung di dalamnya diantaranya tinggi protein, $\beta$-karotein, vitamin $C$, mineral terutama zat besi dan kalsium. Pembuatan yoghurt melibatkan bakteri L.bulgaricus, S. thermophillus. Tujuan penelitian ini untuk mengetahui pengaruh penambahan ekstrak daun kelor dan lama fermentasi terhadap kualitas yoghurt, serta kombinasi terbaik fermentasi dan penambahan ekstrak daun kelor. penelitian ini menggunakan metode rancangan acak kelompok (RAK) dengan 2 faktor dan 3 perlakuan. Penambahan ekstrak daun kelor 3\%, 5\% dan 7\% lama fermentasi menggunakan 24 dan 48 jam. Hasil pengamatan dianalisis menggunakan analisis varian. Apabila terjadi interaksi antara kedua faktor maka dilakukan uji lanjut menggunakan uji DMRT. Pemilihan terbaik dengan metode De Garmo. Perlakuan terbaik terdapat pada perlakuan L2P2 (lama fermentasi 48 jam dan penambahan ekstrak daun kelor 5\%) dengan ketentuan fisiko kimia kadar protein 6,01\%, kadar kalsium 141,44\%, pH 4,49 dan viskositas 35,40 serta nilai organoleptik dengan ketentuan rasa 3,60 (suka), warna 3,75 (suka), aroma 3,15 (netral) dan tekstur 3,70 (suka).

Kata Kunci: Susu, Yoghurt, Kelor, Fermentasi
\end{abstract}

\begin{abstract}
Moringa is a plant that thrives in Indonesia with a variety of benefits contained in them such a highprotein, $\beta$-carotene, vitamin $C$, minerals, especially iron and calcium subtances . making of yoghurt involving of bacteria L.bulgaricus, $S$. thermophillus. This research objective is to determine the effect of extracts of Moringa leaves and long fermentation on the quality of yoghurt, and also the best combination of fermentation and the addition of Moringa leaf extract. This study used the randomized block design (RAK) with 2 factors and 3 repetition. The addition of moringa leaf extract used were $3 \%$, $5 \%$ and $7 \%$, the duration of fermentation used were 24 and 48 hours. The result of this study is analized using analysis of variance. When there is interaction between these two factors then tested farther using DMRT. Selection of the best methods De Garmo. The best treatment contained in L2P2 treatment (fermentation time of 48 hours and the addition of moringa leaf extract 5\%) with the provisions of the physico chemical protein content of $6.01 \%, 141.44 \%$ levels of calcium, pH 4.49 and a viscosity of 35.40 and organoleptic value with provisions sense 3,60 (like), 3.75 color (like), aroma 3.15 (neutral) and texture 3,70 (like).
\end{abstract}

Keywords: Milk, Yoghurt, Moringa, Fermentation

\section{PENDAHULUAN}

Upaya deversifikasi produk olahan akirakir ini semakin berkembang pesat seiring dengan bertamabh cerdasnya masyarakat, terutama olahan prodak dengan segudang manfaat termasuk kelor dan olahan susu. Kelor memiliki kandungan nutrisi yang cukup komplek, menurut Yulianti (2008) dan Etowadi dalam Adeyemi (2014) Potensi yang terkandung dalam daun kelor diantaranya adalah tinggi kandungan protein, $\beta$-karoten, vitamin $\mathrm{C}$, mineral terutama zat besi dan kalsium, bahkan dalam beberapa literatur dijelaskan kelor mempunyai kadar protein 3 kali dari protein telur, 25 kali zat besi serta 3 kali vitamn C bayam, 12 kali kalsium serta 2 kali protein susu.Wahyuni (2013) Tanaman kelor mengandung zat kimia, seperti minyak behen, minyak terbang, emulsin, alkaloida, pahit tidak beracun serta vitamin A, 
B1, B2, dan C. Selain itu kelor juga mengandung lebih dari 90 nutrisi disebut antioksidan alami terbaik. Memiliki sumber serat terbaik, kandungan betakarotine 4 kali lipat lebih besar dari wortel juga terdapat bahan minyak omega 3 dan klorofil

Susu merupakan bahan pangan yang tersusun atas berbagai nilai gizi dengan proporsi seimbang, Maitimu (2012). Akhir-akhir ini penderita alergi terhadap susu sapi kian meningkat, dengan adanya gejala tersebut bukan berarti penderita tidak dapat menikmati kalsium dan nutrisi dari susu. Susu sapi sebagai bahan dasar pembuatan yoghurt memiliki komposisi nutrisi (untuk setiap $100 \mathrm{ml}$ ), antara lain: Vitamin A 158 I.U, Vitamin D 2,0 I.U, Vitamin B6 0,036 mcg, Kalori $69 \mathrm{Kkal}$, Protein 3,3 gram, Lemak 3,7 gram, Laktosa 4,8 gram, Kalsium $125 \mathrm{mg}$, Kasein 2,8 gram, Besi 0,10 mg, Mineral 0,72 gram, Prasetyo (2010).

Sangat disayangkan bila sebagian kecil masyarakat yang alergi terhadap susu jadi tidak bisa mengkonsumsi minuman bergizi tinggi tersebut, maka perlu diadakan suatu prodak dimna masyarakat dapat menikmati manfaat dari susu salah satunya menggunakan fermentasi berupa yoghurt. Yoghurt adalah salah satu bentuk dari olahan Susu fermentasi yang sekaligus menjadi solusi bagi penderita alergi susu sapi dan membantu agar susu mempunyai masa simpan yang lebih lama, Maitimu (2012)

Kekuatan dari pengombinasian antara kelor dan yoghurt adalah sama-sama mengandung kalsium, protein, serta mineral yang tinggi serta sangat jarang diketemukan olahan susu yang dikombinasikan dengan sayuran. Penambahan ekstrak daun kelor akan berpengaruh terhadap aroma,rasa,warna, tekstur dan kandungan gizi produk yoghurt kelor sehingga perlu dikaji presentase penambahan ekstrak daun kelor dan lama fermeentasi yang paling tepat sehingga memiliki kualitas fisiko kimia dan organoleptik yang baik.

\section{METODE PENELITIAN}

Alat-alat yang dipergunakan untuk pembuatan yoghurt kelor (Moringa oleifera. L) adalah: kompor gas, dandang, pisau stainlees steel, sendok makan, sendok teh, baskom, botol, timbangan, termometer, alkohol dan tisue.

Bahan-bahan yang digunakan dalam pembuatan yoghurt kelor (Moringa oleifera. L) adalah: susu murni, gula, starter yoghurt, kelor (dalam bentuk ekstrak) dan air aquades

Percobaan dilakukan dengan menggunakan rancangan acak kelompok (RAK) dengan 2 faktor, Faktor 1 : lama fermentasi terdiri dari 2 level $: \mathrm{L} 1=24$ jam (1 hari), L2 = 48 jam (2 hari) Faktor 2 : prosentase penambaha ekstrak kelor, konsentrasi ekstrak kelor terdiri dari 3 level :P1 = 3\% Ekstrak Kelor, P2 = 5\% Ekstrak Kelor, P3 = $7 \%$ Ekstrak Kelor. Jadi penelitian ini terdiri dari 6 kali percobaan.

1. L1 X P1 (lama fermentasi 24 jam dan penambahan 3\% ekstrak kelor)

2. L1 X P2 (lama fermentasi 24 jam dan penambahan $5 \%$ ekstrak kelor)

3. L1 X P3 (lama fermentasi 24 jam dan penambahan $7 \%$ ekstrak kelor)

4. L2 X P1 (lama fermentasi 48 jam dan penambahan 3\% ekstrak kelor)

5. L2 X P2 (lama fermentasi 48 jam dan penambahan $5 \%$ ekstrak kelor)

6. L2 X P3 (lama fermentasi 48 jam dan penambahan $7 \%$ ekstrak kelor)

\section{Pelaksanaan Penelitian}

Proses pembuatan yoghurt kelor (Moringa Oleifera L) melalui tiga bagian yaitu bagian pembuatan ekstrak kelor, pembuatan yoghurt dan pembuatan yoghurt esktrak daun kelor.

Pembuatan ekstrak kelor diawali dengan pengumpulan bahan (kelor) setelahnya kelor tersebut dipisahkan antara ranting dan daun kelor setelah itu daun kelor dicuci, proses pencucian bertujuan untuk membuat daun kelor bersih dan higienis. Setelah pencucian dilakukan penimbangan $(100$ gr $)$ setelah proses penimbangan dilakukan proses penghancuran dengan penambahan $100 \mathrm{ml}$ air. Setelah itu kelor yang sudah hancur disaring (pres) menggunakan kain dan di peroleh ekstrak daun kelor.

Pembuatan yoghurt diawali dengan penyiapan bahan baku berupa susu sapi murni (3 liter) setelahnya susu sapi di rebus hingga mencapai suhu kurang lebih $75^{\circ} \mathrm{C}$ agar protein susu tidak hancur, perebusan bertujuan membunuh mikroorganisme yang bersifat toksik sehingga proses homogenisasi dapat tercapai. Setelah melalui proses perebusan susu didinginkan sampi suhu $45^{\circ} \mathrm{C}$, pendinginan ini bertujuan untuk memberi lingkungan yang optimal bagi bakteri asam laktat sehingga dapat berkembang biak dengan baik. Setelah suhu $45^{\circ} \mathrm{C}$ 
starter yoghurt dimasukan (12 liter susu $250 \mathrm{ml}$ starter). Setelah proses penambahan starter susu harus diinkubasi selama kurang lebih 24 jam dan 48 jam (2 perlakuan).

Pembuatan yoghurt kelor dimulai dengan persiapan yoghurt dan ekstrak daun kelor, dan setelahnya dilaksanakan penambahan dan perlakuan sesuai rancangan percobaan.

Pengamatan sifat fisiko kimia meliputi analisa pH (SNI 06-6989.11-2004), analisa kadar kalsium (Titrasi, Apriantono, 1989), analisa viskositas (sudarminto dan susanto, 1998) serta analisa kadar protein (metode kjeldahl), pengamatan organoleptik meliputi pengamatan rasa, warna, aroma dan tekstur.

Data dari pengamatan sifat fisik, kimia dilakukan uji analisis ragam ANOVA dengan selang kepercayaan $5 \%$ dan $1 \%$. Apabila ditemukan pengaruh terhadap salah satu variabel maka dilanjutkan dengan uji DMRT dengan selang kepercayaan $1 \%$. Untuk uji organoleptik menggunakan uji Friedman. Perlakuan terbaik menggunakan metode indeks efektifitas.

\section{HASIL DAN PEMBAHASAN}

\section{Kadar Protein}

Berdasarkan hasil analisis kadar protein yoghur ekstrak daun kelor (Moringa Oleifera.L) diperoleh rata-rata kadar protein 5,02\% sampai $6,53 \%$. Analisis ragam menunjukan bahwa kombinasi perlakuan lama fermentasi susu dan prosentase penambaha ekstrak daun kelor (Moringa Oleifera.L) berpengaruh tidak nyata terhadap kadar protein yoghurt kelor, kombinasi perlakuan terbaik lama fermentasi dan prosentase penambahan ekstrak daun kelor terdapat pada perlakuan L2P3 (fermentasi selama 48 jam dan penambahan ekstrak daun kelor 7\%). Rata-rata nilai protein pada setiap perlakuan dapat dilihat pada gambar grafik 1 .

Gambar 1 memperlihatkan bahwa lama fermentasi berpengaruh terhadap kadar protein yoghurt. Seperti pendapat Suprihana (2012) semakin lama fermentasi mengakibatkan kadar protein semakin meningkat, karena semakin lama fermentasi bakteri asam laktat yang tumbuh semakin banyak, sehingga kandungan protein meningkat. Wardhani (2015) semakin lama fermentasi maka akan meningkartkan kadar asam laktat, lemak, protein dan viskositas.

Prosentase penambahan ekstrak daun kelor diketahui juga mempengaruhi kadar protein yoghurt hal ini karna kelor mengandung protein yang tinggi. Seperti pernyataan Joni MS dalam Zakariya (2012) protein daun kelor setara dengan 9 kali protein yang terdapat pada yoghurt. Fungli dalam yulianti (2008) menyatakan potensi yang terkandung dalam daun kelor diantaranya tinggi protein, betakarotin, vitamin $\mathrm{C}$, mineral, terutama zat besi dan kalsium. Etowadi dalam Adeyemi (2014) kandungan protein daun kelor setara dengan dua kali protein yang terdapat dalam susu.

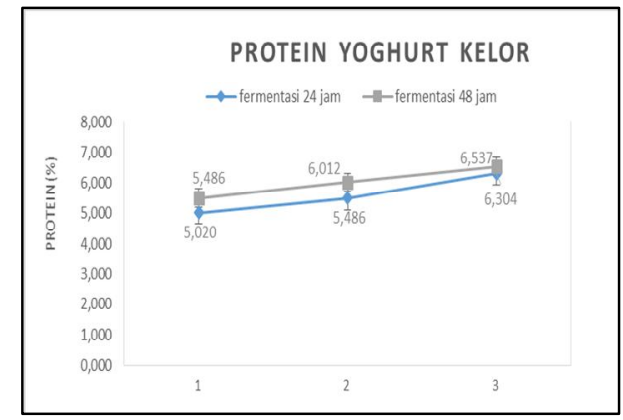

Gambar 1 Grafik Rata-Rata Kadar Protein (\%) Yoghurt Kelor

\section{pH}

Berdasarkan hasil analisis nilai $\mathrm{pH}$ yoghur ekstrak daun kelor (Moringa Oleifera.L) diperoleh rata-rata 4,343 sampai 4,627. Analisis ragam menunjukan bahwa kombinasi perlakuan lama fermentasi susu dan prosentase penambaha ekstrak daun kelor (Moringa Oleifera.L) berpengaruh sangat nyata terhadap Nilai $\mathrm{pH}$ yoghurt kelor. kombinasi perlakuan terbaik lama fermentasi dan prosentase penambahan ekstrak daun kelor terdapat pada perlakuan L2P1 (fermentasi selama 48 jam dan penamhan ekstrak daun kelor 3\%).Rata-rata nilai $\mathrm{pH}$ pada setiap perlakuan dapat dilihat pada gambar grafik 2 .

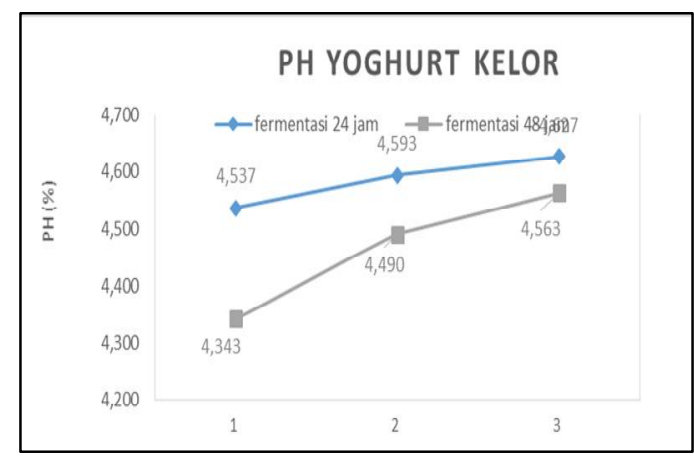

Gambar 2. Grafik Rata-Rata Nilai pH Yoghurt Kelor 
Gambar 2 memperlihatkan bahwa lama fermentasi berpengaruh terhadap nilai $\mathrm{pH}$ yoghurt. Seperti pernyataan Kartikasari (2014) selama fermentasi asam laktat yang tebentuk akan disekresikan keluar sel dan terakumulasi dalam media fermentasi sehingga makin lama waktu fermentasi, jumlah total asam yang terakumulasi semakin meningkat dan menurunkan pH. Zakariya (2013) selama fermentasi bakteri asam laktat akan mendegradasi laktosa susu menjadi asam laktat sehingga menurunkan kadar $\mathrm{pH}$. Sebayang (2006) fermentasi yang dilakukan selama 48 jam dapat menurunkan $\mathrm{pH}$. Tammim dalam Prasetyo (2010) fermentasi dari gula susu (laktosa) menjadi asam laktat sehingga keasaman susu naik disertai dengan penurunan $\mathrm{pH}$. Wardhani (2015) mengatakan, semakin lama fermentasi maka akan menurunkan $\mathrm{pH}$ dan kadar glukosa.

Prosentase penambahan ekstrak daun kelor diketahui membuat $\mathrm{pH}$ yoghurt semakin naik. Hal ini dimungkinkan karna ekstrak daun kelor mempuyai $\mathrm{pH}$ yang mengarah pada netral seperti peryataan yulianti (2008) $\mathrm{pH}$ kelor berkisar antara 5,8-6,0.

\section{Kadar Kalsium}

Berdasarkan hasil analisis yoghur ekstrak daun kelor (Moringa Oleifera.L) diperoleh ratarata kadar kalsium $133,81 \%$ sampai $146,64 \%$. Analisis ragam menunjukan bahwa kombinasi perlakuan lama fermentasi susu dan prosentase penambaha ekstrak daun kelor (Moringa Oleifera.L) tidak berpengaruh nyata terhadap kadar kalsium yoghurt kelor. Kombinasi perlakuan terbaik lama fermentasi dan prosentase penambahan ekstrak daun kelor terdapat pada perlakuan L2P3 (fermentasi selama 48 jam dan penambahan ekstrak daun kelor sebesar 7\%). Rata-rata kadar kalsium pada setiap perlakuan dapat dilihat pada gambar grafik 3 .

Gambar 3. memperlihatkan bahwa lama fermentasi berpengaruh terhadap kadar kalsium yoghurt. Menurut Widodo (2012) lama fermentasi juga membuat beberapa Kandungan mineral pada yoghurt meningkat, khususnya kalsium, fosfor, dan kalium.

Yoghurt Kelor

Prosentase penambahan ekstrak daun kelor diketahui membuat kadar kalsium yoghurt semakin meningkat, hal ini disebabkan kandunga kalsium kelor sangat tinggi, Seperti pernyataan Joni Ms dalam Rudianto (2013), Amzu (2014)
Dalam 100 gram daun kelor setara dengan 4 kali kalsium dalam susu. Dan pernyataan fungli dalam yulianti (2008) potensi yang terkandung dalam daun kelor diantaranya tinggi protein, betakarotin, vitamin $\mathrm{C}$, mineral, terutama zat besi dan kalsium serta pernyataan Nugroho (2014:175) kelor merupakan

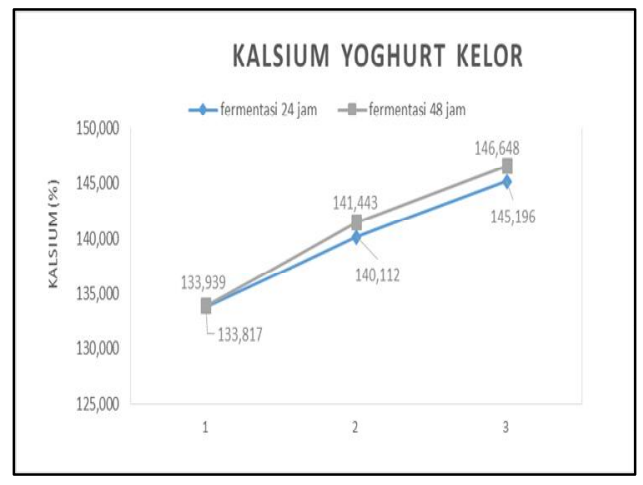

Gambar 3. Grafik Rata-Rata Kadar Kalsium sumber protein, Kalsium dan zat besi.

\section{Viskositas}

Berdasarkan hasil analisi yoghurt kelor (Moringa Oleifera. L) diperoleh rata-rata nilai viskositas $32,46 \mathrm{cps}$ sampai $37,30 \mathrm{cps}$. Analisis ragam menunjukan bahwa kombinasi perlakuan lama fermentasi susu dan prosentase penambahan ekstrak daun kelor (Moringa Oleifera.L) berpengaruh sangat nyata terhadap viskositas yoghurt kelor. Kombinasi perlakuan terbaik lama fermentasi dan prosentase penambahan ekstrak daun kelor terdapat pada perlakuan L2P3 (lama fermentasi 48 jam dan penambahan ekstrak daun kelor 7\%). Rata-rata nilai viskositas pada setiap perlakuan dapat dilihat pada gambar grafik 4 .

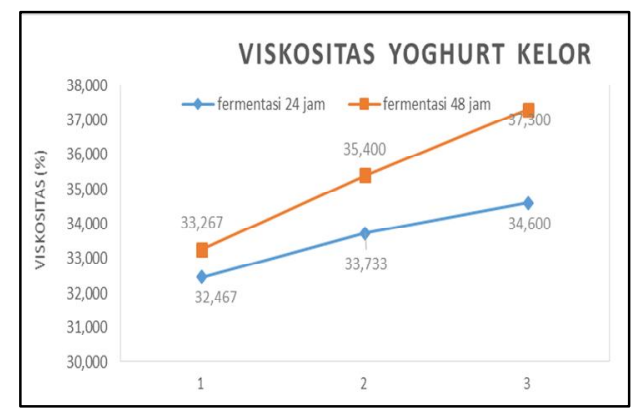

Gambar 4. Grafik Rata-Rata Nilai Viskositas Yoghurt Kelor 
Gambar 4. memperlihatkan bahwa lama fermentasi berpengaruh terhadap nilai viskositas yoghurt. Hal ini dimungkinkan karna semakin lama fermentasi membuat protein mengumbal dan membuat viskositas naik seperti pernyataan Harjiyanti (2013) terbentuknya asam laktat oleh bakteri asam laktat menyebabkan peningkatan total asam sehingga kasein mengalami koagulasi pementuk gel. Terbentuknya gel menyebabkan tekstur semi padat sehingga semakin lama viskositas naik. Mikulec (2009) gula susu atau laktosa difermentasi oleh bakteri asam laktat yang menyebabkan karakteristik yoghurt menjadi menggumpal, proses ini membuat yoghurt memiliki rasa yang menyegarkan serta tekstur atau viskositas yoghurt seperti puding. Suprihana (2012) semakin lama fermentasi susu mengakibatkan viskositas naik. Sutedjo (2015) Semakin lama waktu fermentasi yang diterapkan semakin tinggi pula nilai viskositas yoghurt yang didapatkan.

Prosentase penambahan ekstrak daun kelor diketahui juga membuat viskositas semakin naik, sepeti pernyataan Triyono dalam Wardhani (2015) semakin tinggi kadar protein dalam yoghur maka kekentalan (viskositas) yoghurt semakin meningkat.

\section{Hasil Uji Organoleptik}

Uji Organoleptik dilakukan pada 6 sempel prodak yoghurt kelor dengan menggunakan 20 panelis dengan spesifikasi agak ahli, uji organoleptik dimaksutkan guna menilai daya terima konsumen terhadap prodak yang dihasilkan seperti yang dikemukakan Askar (2005) uji Organoleptik dimaksutkan untuk mengetahui tingkat kesukaan dan penerimaan panelis terhadap prodak. 6 sempel prodak yang diujikan adalah yoghurt dengan penambahan ekstrak daun kelor 3\%, 5\%, dan 7\% serta lama fermentasi 24 jam dan 48 jam, produk yoghurt ini memiliki citarasa khusus yaitu rasa asam dengan perpaduan rasa dari daun kelor. Uji organoleptik meliputi uji Rasa, Aroma, Warna dan tekstur.

\section{Rasa}

Kecenderungan kesukaan panelis terhadap rasa yoghurt dengan berbagai perlakuan dapat dilihat padagambar grafik 5 .

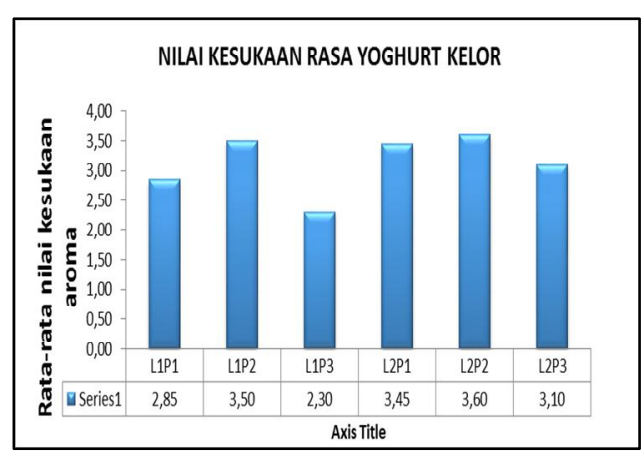

Gambar 5. Histogram Rata-rata Kesukaan RasaYoghurt Kelor

Dari hasil Uji organoleptik terhadap 20 panelis, penilaian terbaik terhadap rasa yoghurt kelor terdapat pada perlakuan L2P1 (lama fementasi 48 jam dan penambahan ekstrak daun kelor 3\%) dengan rata-rata nilai 3,30 (netral) dan penilaian terendah terhadap rasa yoghurt kelor terdapat pada perlakuan L1P3 (fermentasi 24 jam dan penambahan ekstrak daun kelor 7\%) sebesar 2,65 (netral) dengan rata-rata skor 2,82 (netral).

\section{Warna}

Kecenderungan kesukaan panelis terhadap warna yoghurt dengan berbagai perlakuan dapat dilihat padagambar grafik 6

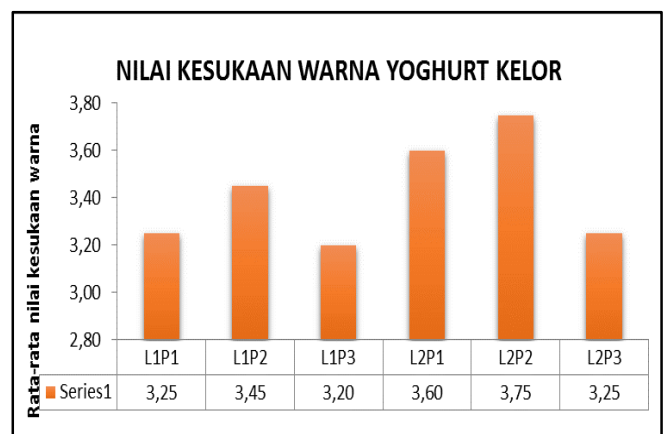

Gambar 6. Histogram Rata-rata Kesukaan Warna Yoghurt Kelor

Dari hasil uji organoleptik terhadap 20 panelis, penilaian terbaik warna terdapat pada perlakuan L2P2 (lama fermentasi 48 jam dan penambahan ekstrak daun kelor 5\%) dengan ratarata nilai 3,75 (suka) dan rata-rata skor 4,25 dan nilai terkecil terdapat pada perlakuan L1P3 (fermentasi 24 jam dan penambahan ekstrak daun kelor 7\%) sebesar 3,20 (netral). 
Aroma

Kecenderungan kesukaan panelis terhadap aroma yoghurt dengan berbagai perlakuan dapat dilihat pada gambar grafik 7 .

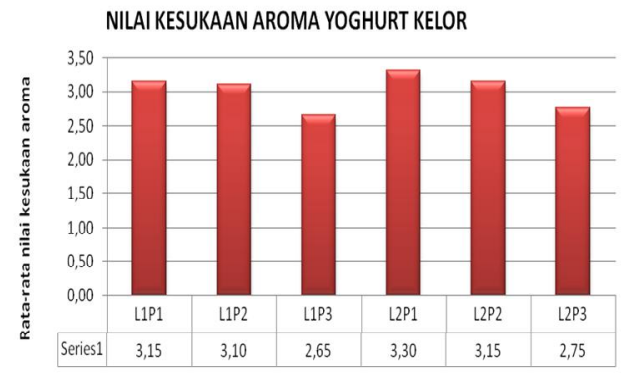

Gambar 7. Histogram Rata-rata Kesukaan Aroma Yoghurt Kelor

Dari hasil Uji organoleptik terhadap 20 panelis, penilaian terbaik terhadap aroma yoghurt kelor terdapat pada perlakuan L2P1 (lama fementasi 48 jam dan penambahan ekstrak daun kelor 3\%) dengan rata-rata nilai 3,30 (netral) dan rata-rata skor 3,97 (suka) dan penilaian terendah terhadap aroma yoghurt kelor terdapat pada perlakuan L1P3 (fermentasi 24 jam dan penambahan ekstrak daun kelor 7\%) sebesar 2,65 (netral).

\section{Tekstur}

Kecenderungan kesukaan panelis terhadap rasa yoghurt dengan berbagai perlakuan dapat dilihat padagambar grafik 8 .

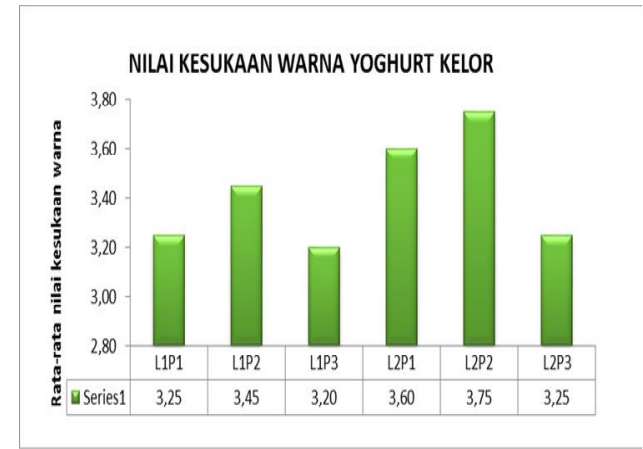

Gambar 8. Histogram Rata-rata Kesukaan Tekstur Yoghurt Kelor .

Dari hasil uji organoleptik terhadap 20 panelis, penilaian terbaik warna terdapat pada perlakuan L2P2 (lama fermentasi 48 jam dan penambahan ekstrak daun kelor 5\%) dengan ratarata nilai 3,75 (suka) dan rata-rata skor 4,25 dan nilai terkecil terdapat pada perlakuan L1P3 (fermentasi 24 jam dan penambahan ekstrak daun kelor 7\%) sebesar 3,20 (netral) .

\section{Indeks Efektifitas}

Penentuan pelaksanaan terbaik yoghurt ekstrak daun kelor dilakukan dengan menggunakan metode indeks efektivitas. Metode ini dilakukan pada parameter kimiawi yang meliputi uji Kadar protein, kalsium, $\mathrm{pH}$ dan viskositas. serta uji organoleptik meliputi rasa, warna, aroma dan tekstur. Bobot parameter tertinggi adalah kadar protein sebesar 0,203 diikuti oleh rasa (orlep) sebesar 0,179, kadar kalsium sebesar 0,158, warna (orlep) sebesar 0,143, aroma (orlep) sebesar 0,118, tekstur (orlep) sebesar 0,090, viskositas sebesar 0,057 dan terakhir $\mathrm{pH}$ sebesar 0,051 Bobot parameter disajikan pada gambar 9 .

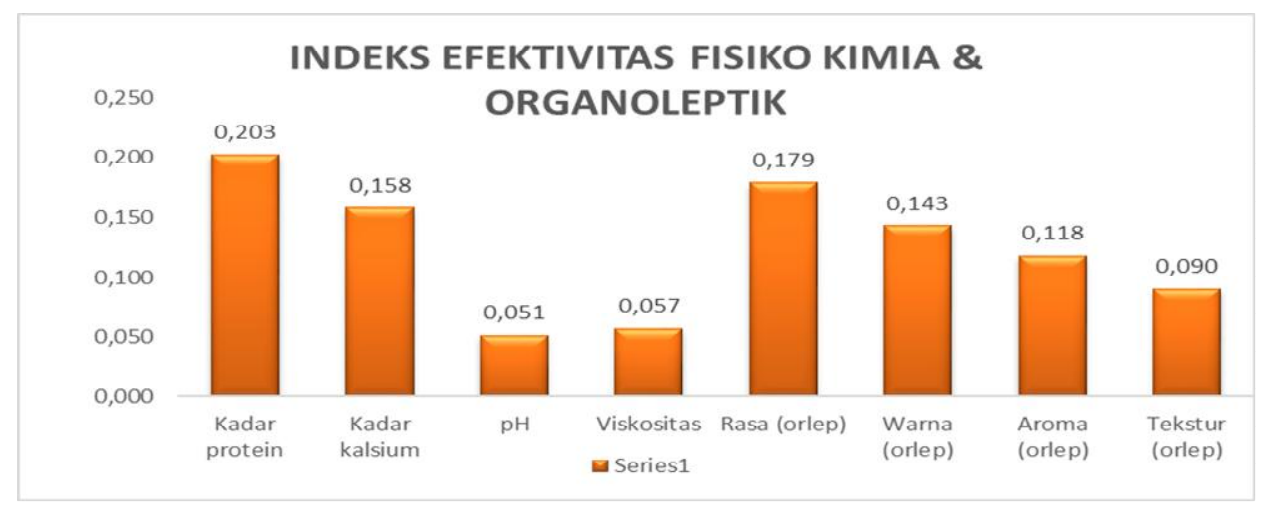

Gambar 9. Indeks Efektifitas Fisiko Kimia dan Organoleptik 


\section{KESIMPULAN DAN SARAN}

\section{Kesimpulan}

1. Perlakuan lama fermentasi yoghurt dan penambahan ekstrak daun kelor terbaik (fisiko kimia) terdapat pada perlakuan L2P3 (fermentasi 48 jam dan penambahan ekstrak daun kelor 7\%) dengan kriteria kadar Protein, $6,53 \%$, kadar Kalsium, 146,65\%, pH, 4,56 dan viskositas, 37,30 .

2. Lama fermentasi yoghurt dan penambahan ekstrak daun kelor terbaik (organoleptik) terdapat pada perlakuan L2P2 (fermentasi 48 jam dan penambahan ekstrak daun kelor 5\%) dengan kriteria penilaian Rasa, 3,60, Warna, 3,75, Aroma, 3,15 dan tekstur 3,70.

3. Kombinasi perlakuan terbaik fisiko kimia dan organoleptik terdapat pada perlakuan L2P2 (fermentasi 48 jam dan penambahan ekstrak daun kelor 5\%) dengan kriteria, kadar Protein, 6,01\%, kadar Kalsium, 141,44\%, $\mathrm{pH}$, 4,49, viskositas, 35,40, Rasa, 3,60,

\section{Saran} Warna, 3,75, Aroma, 3,15 dan tekstur 3,70.

1. Penelitian selanjutnya diharapkan dapat meneliti pemanfaatan daun kelor secara spesifik seperti daun kelor ranting ke 3 dari pucuk, sehingga nutrisi dalam kelor diketahui secara akurat.

2. Penelitian selanjutnya diharapkan dapan meneliti untuk menghilangkan bau langu dan rasa khas kelor yang dominan sehingga daya terima konsumen terhadap prodak kelor dapat meningkat.

3. Penelitian selanjutnya diharapkan dapat meneliti persen kenaikan kalsium selama proses fermentasi.

\section{DAFTAR PUSTAKA}

Adeyemi, O.S, Elebiyo, T.C. 2014. Moringa Oleifera Supplemented Diets Prefented Nickel-Induced Nephrotocity in Wistar Rate. Journal of Nutrition and Metabolism Vol 4 (2):1-8

Amzu, E, 2014. Kampung Konservasi Kelor: Upaya Mendukung Gerakan Nasional Sadar Gizi dan Mengatasi Malmnutrisi di Indonesia. Jurnal Risalah kebijakan pertanian dan lingkungan Vol 01 (2):8691.

Harjiyanti, M.D, Pramono, Y.B, Mulyani, S. 2013. Total Asam Viskositas dan Kesukaan
Yoghurt Drink dengan Sari Buah Mangga (mangiferaindicia) sebagai Perisa Alami. Jurnal Aplikasi Teknologi Pangan Vol 2 (2): 104-107.

Kartikasari, D. I, Nisa, F.C. 2014. Pengaruh penambahan sari buah sirsak dan lama fermentasi terhadap karakteristik fisik dan kimia yoghurt. Jurnal Pangan dan Agrobisnis.02 (04):239-248.

Maitimu, C, V, Anang,M, legowo, \& Ahman N albaarri., 2012. Parameter Keasaman Susu Pasteurisasi dengan Penambahan Ekstrak Daun Aileru (wrightia caligria). Jurnal Aplikasi Teknologi Pangan.01 (1):07-11.

Mekulec, D, P \& Niketi G,B. 2009. Compositional Characteristics of Comersial Yoghurt Based on Quantitative Determination of Viable Lactid Acid Bacteria. Jurnal APTEFF Vol 40 (1):8794.

Nugroho, B.A, Miswadi, S.S \& Santosa, N.B. 2014. Penggunakan Serbuk Biji Kelor untuk Menurunkan Kadar Pb, Kekeruhan dan Intensitas Warna. Journal of Chemical Science Vol 03 (3): 174-178.

Prasetyo, H., 2010. Pengaruh Penggunaan Starter Yoghurt pada Level Tertentu terhadap Karakteristik Yoghurt yang Dihasilkan. Skripsi. Surakarta. Fakultas pertanian. Universitas Sebelas Maret.

Rudianto, Syam, A\&Alharini,S., 2013. Studi Pembuatan Dan Analisis Zat Gizi Pada Produk Biskuit Moringa Oleifera Dengan Subtitusi Tepung Daun Kelor. Program Studi Ilmu Gizi Fakultas Kesehatan Masyarakat Universitas Hasanuddin Makasar.

Sebayang, F. 2006. Pembuatan Ethanol dan Molase secara Fermentasi mMenggunakan $\mathrm{Sel}$ Saccharomyces cerevisiae yang Terimobilisasi pada Kalsium Alginat. Jurnal Teknologi Proses Vol 5 (2) 75-80.

Suprihana. 2012. Pengaruh Lama Penundaan dan Suhu Inkubasi terhadap Sifat Fisik dan Kimia Yoghurt dari Susu Sapi Kadaluarsa. Jurnal AGRIKA Vol 6 (1): 94-102.

Wahyuni, S dkk., 2013. Uji Manfaat Daun Kelor (Moringa Olerifera l) untuk Mengobati Penyakit Hepatitis B. Jurnal Kesmadaska Vol 3 (7):100-103. 
Wardhani, D.H, Maharani, D, C \& prasetyo E, A. 2015. Kajian Pengaruh cara Pembuatan Susu Fermentasi terhadap Karakteristik Yoghurt Jagung Manis. Jurnal Momentum Vol 11 (1): 7-12.

Widodo, W, 2002. Bioteknologi Fermentasi Susu. Riset. Pusat Pengembangan Bioteknologi Universitas Muhammadiyah malang.

Yulianti, R. 2008. Pembuatan Minuman Jeli Daun Kelor (Moringa Oleifera Lamk) Sebagai Sumber Fitamin $C$ dan $\beta$-Karoten. Skripsi: Bogor: Fakultas Pertanian Institut Pertanian Bogor.
Zakaria, Tamrin, A, Sirajudin\&Hartono, R., 2012. Penambahan Tepung Daun Kelor pada Menu Makanan Sehari-hari dalam Upaya Penanggulangan Gizi Kurang pada Anak Balita. Jurnal Media Gizi Pangan. 13 (1):41-47.

, Y, Yurliasni, Delima, M, Diana E. 2013. Analisa Keasaman dan Total Bakteri Asam Laktat Yoghurt akibat Bahan Baku dan Presentase Lactobacillus Casei yang Berbeda. Jurnal Agripet Vol 12 (2):31-35. 